\title{
NEW PERSPECTIVES IN THE SOURCES OF STORY OF CORPORATIVISM IN ITALY
}

\author{
NOVAS PERSPECTIVAS NAS FONTES DE HISTÓRIA DO \\ CORPORATIVISMO EM ITÁLIA
}

DOI: http//dx.doi.org/10.15448/2178-3748.2016.2.24560

Francesca Nemore

Doutora - Università di Roma La Sapienza

E-mail: francesca.nemore@uniroma1.it

\begin{abstract}
RESUMO: A reconstrução histórica do corporativismo italiano, durante o período fascista, tornou-se interligados e tem sido dificultada pela história de um arquivo perdido. A história da dispersão do arquivo é interessante porque não é apenas uma história de arquivo mas tece e mantém a história política e econômica do período fascista, mas também a do período anterior ea próxima. O arquivo que você está falando é a do Ministério das Corporações: o corpo principal do governo de economia italiana sob o fascismo. O tema deste trabalho é a análise das teorias "fantasiosas" ao longo dos anos justificaram o desaparecimento de arquivo e reconstrução de arquivo através de si mesmo fontes subsidiárias. A idéia de buscar a documentação, fragmentado em vários locais, e em seguida para configurar um guia para as fontes para a história do Ministério das Corporações, foi fundada em 2009 por algumas considerações, muito discutida na recente história italiana, relativa à política econômica fascista e pouco verificável na ausência de fontes institucionais diretos que lhe permitam dar uma confirmação ou negação às expectativas iniciais, tendo em conta de um ponto de vista de um objecto institucional, o papel dos quais (a longo mal avaliadas) parece muito significativo hoje. É, na verdade, razoável acreditar que houve uma continuidade entre as políticas de intervenção estatal do fascismo e as aplicadas antes dos governos liberais do início dos anos 900 e, em seguida, nos primeiros cinquenta anos de história republicana, tanto na estrutura administrativa tanto no estritamente industrial.
\end{abstract}

PALAVRAS-CHAVE: Ministério das Corporações, fascismo, política industrial.

\begin{abstract}
The historical reconstruction of the Italian corporatism, during the fascist period, has become intertwined and has been hampered by the story of a lost archive. The story of the archive dispersion is interesting because it is not just an archival history but weaves and holds the political and economic history of the Fascist period, but also that of the previous period and the next. The archive that we are talking about is that of the Ministry of Corporations: the main body of the Italian economy government under fascism. The subject of this work is the analysis of "fanciful" theories over the years justified the archive disappeared and the reconstruction through archive subsidiary sources same. The idea of seeking the documentation, fragmented in various locations, and then to set up a guide sources for the history of the Ministry of Corporations, was founded in 2009 by some considerations, much discussed in recent Italian historiography, on the economic policy of the fascist period and little verifiable in the absence of direct institutional sources that enable it to give a confirmation or denial to initial hypotheses, taking into account the subject of an institutional point of view the role of which (long little rated) appears very significant today. It is, in fact, reasonable to believe that there was a continuity between the policies of state intervention economy of fascism and those applied prior to the liberal governments and then in the first fifty years of Republican history, both in the administrative structures in both the strictly industrial.
\end{abstract}

KEYWORDS: Ministry of corporations; Fascism Industrial policies. 
The historical reconstruction of what has represented corporatism in Italy during the fascist period has long been obstacle by the almost total disappearance of the archives of what used to be the principal administrative organ for the realization out of corporative policies concerning the economy and the reports of meetings: the Ministry of corporations. The archive has been almost totally lost, concerning this Anna Pia Bidolli, in an article that appeared in Rassegna degli Archivi di Stato states:

\begin{abstract}
This missing section of the Ministry of corporations, seems destined to remain so incomplete, except in very small measure. Except for the section of the mines and the one on patents and trademarks for which there exists an almost complete continuity since the Union of Italy till after Second world war. The remaining part of documentation is totally missing for the fascist period. The soundings, unfortunately negative, that have been made in the ministerial records, make one think, in fact, of an irremediable lost. (BIDOLLI, 1989, pp. 98-100)
\end{abstract}

Besides the two fonds mentioned by Bidolli, other fonds are well stored in the Archivio centrale dello Stato in the years following the one during which the article was written, contain documentary material produced by Ministry of corporations and have a complete continuity from the Union of Italy till the Republic. This concerns the circulars from and for the Ministry, folders concerning the employees and the fond Pesi e misure e marchio e saggio dei metalli preziosi, of which, are missing, those from the year 1960 onwards, and which are however to be found in the ministerial stores.

Nevertheless, the rest of the documentation is irremediably lost as expressed in one of their articles on the economy ministries, Linda Giuva e Maria Guercio:

\footnotetext{
The archive of the Ministry of corporations constitutes, for example, one of the many mysteries of which the Italian history of archives is full. In spite of the detailed researches carried out in the stores of the Ministry of industry, which, during the period of suppression, had inherited its competences, over and above the seat of via Veneto, no traces were found of the huge documentation which should have formed the archive of Ministry. (GIUVA, GUERCIO, 1992, p. 20).
}

In order to justify this lack of documents, over a period of years, a big number of unlikely reasons were given; for many years, in fact, the employees of the Archivio centrale dello Stato, presents requests for documentary material and carry out studies and surveys in the various stores of the Ministry, without, however, succeeding in finding the lost material.

The archive of Ministry would have certainly presented a source of primary importance for the understanding of a number of considerations, very often discussed in the recent Italian historiography, on the continuity of economic and social policies presented by 
fascism and those practiced by the liberal governments of the beginnings of the years ' 900 and then continued after the Second World War by the governments of the Republic, both in the administrative orders and in those properly industrial. For this reason, the author of this paper, dedicated the research for the doctoral thesis in archival science to its reconstruction, through the census of the complementary documentation present in the various boards with which he was in touch, and the coordination of such documentation with that found and still preserved by the Ministry, especially that documentation kept at the Archivio centrale dello Stato. ${ }^{1}$ Starting from it, as I will try to show, it is possible to reconstruct the modus operandi of the Ministry and of the political reasons of those who contributed to its creation and administration.

One can almost certainly affirm that a huge part of the archive has been lost because of the events of the war ${ }^{2}$, especially during the transfers of the seats of the ministries in the North of Italy after the institution of the Repubblica Sociale Italiana (GENCARELLI, 1979). The thesis concerning the transfer to the North of the archive of Ministry can be largely confirmed by the presence in various archives of public entities and of ministries in the correspondence and notes concerning the sending, in large quantities of documents to their sub-centers between the regions of Lombardy and the Veneto.

A very suggestive and most probably true, is the hypothesis, very often presented and suggested by the employees of the Ministry of industry to the archivists responsible of the surveys carried out, is the one according to what these employees thought, this loss of documents was mainly due to flooding caused by an underground river, which happened presumably during the period between the years ' 40 and ' 50 , in the repository of via Veneto 33 in Rome, which was the headquarter of the Ministry of industry, commerce and handicraft to which had been passed archive of the Ministry of corporations. Other employees speak of

\footnotetext{
${ }^{1}$ Dottorato di ricerca in scienze librarie e documentarie, XXV ciclo, Guida alle fonti sussidiarie per la storia del Ministero delle Corporazioni.

${ }^{2}$ Cfr. GIUBBINI, Giovanna. Gli archivi italiani durante la seconda guerra mondiale. In: CAPACCIONI, Andrea; PAOLI, Andrea; RANIERI, Ruggero Le biblioteche e gli archivi durante la seconda guerra mondiale. Il caso italiano. Bologna: Pendragon, 2007, pp. 211-229; RANIERI, Ruggero. Il ruolo degli alleati nella preservazione delle biblioteche e degli archivi durante l'esperienza di liberazione/occupazione (1943-46). In: Le biblioteche e gli archivi..., pp. 167-210; RE, Emilio. Gli archivi italiani durante la guerra. Archivio della Deputazione romana di Storia patria, vol. LXIX (XII n. s.), fascc. I-VI, Roma 1946; Id. I danni di guerra subiti dagli archivi italiani. Notizie Degli Archivi di Stato, aa. IV-VII, n.u., Istituto Poligrafico dello Stato, Roma 1950; Ministero dell'Interno, Direzione generale dell'amministrazione civile, Ufficio centrale Archivi di Stato. Gli archivi di Stato al 1952. Roma: Istituto Poligrafico dello Stato, 1954; PAOLI, Andrea. "Salviamo la creatura": protezione e difesa delle biblioteche italiane nella seconda guerra mondiale. Roma: AIB, 2003; BATTELLI, Giulio. Archivi, biblioteche ed opere d'arte: ricordi del tempo di guerra 1943-1946. Miscellanea Bibliotecae apostolicae vaticanae, 7, Città del Vaticano, Biblioteca Apostolica Vaticana, 2000; TOSCANO, Mario. Gli archivi segreti d palazzo Chigi catturati dai nazisti nel 1945. Nuova antologia, XCVI (1961).
} 
an underground bunker, presumably the room earmarked for the minister of the corporations, situated in a hypothetical fourth floor below ground, not marked in the original projects and in the maps of the palace ${ }^{3}$, and whose presence would have been hidden from outside through the closure of the whole floor. The two reasons given by the employees of the Ministry of industry, who had been present at these events and who, therefore, were the only direct source on which to found a reconstruction of the reasons of the dispersal of the archive, still leave open certain doubts and suggestions concerning the reason for their disappearance. At one time, they even thought that the archive had been lost voluntarily in order to hide connection of the big Italian industry with fascism; nevertheless, this hypothesis seems to have been denied by the presence in the archive of the Confindustria of a great documentary millstone concerning the relationships between the association, the industrialists and the Ministry.

The idea of the Ministry as the center of the fascist economic policy, or rather, as the fulcrum of the "new fascist state", is already evident from the first words of the originator Giuseppe Bottai, first undersecretary and then minister of corporations, when he affirms that "That the Ministry of the corporations is in fact more than just a Ministry, an organ of general coordination", the center of the entire economic policy of fascism. In a note of 1927 , addressed to the minister of National economy, Belluzzo, Bottai insisted that the Ministry was not only a means of political and administrative control on the productive forces, but was, above all, as upheld by Mussolini, in his inaugural address as minister of the Corporations, "The organ of the integral corporation". 5

According to the intentions of the government the institutions of the Ministry responded to two predominant necessities: the desire of fascism to present itself as the peacemaker between the social contrasts which had characterized the "biennio rosso" and the will of the regime to bring to its end the effort to make the State totally fascist, though the creation of structures, and more exactly, the corporations, which would have acted as the central collector of the economic and social life of the Country. The essential law for the juridical discipline of the relationships of work was the so-called "trade union law", of 3 April 1926 , no. $563^{6}$, with which were established the norms concerning the juridical recognition by

\footnotetext{
3 BORSI, Franco; MOROLLI, Gabriele; FONTI, Daniela; BATTAGLIA, Adolfo. Il palazzo dell'Industria. Roma: Editalia, 1986.

${ }^{4}$ Archivio Centrale dello Stato (ACS), Presidenza del Consiglio dei Ministri (PCM), Gabinetto, Atti, 1927, fasc. 1.1.2/1102.

${ }^{5}$ ACS , Archivi fascisti, Carte della cassetta di zinco, Autografi del duce, sc. 3, cart. 4.1.6.

${ }^{6}$ ACS , Raccolta ufficiale delle leggi e dei decreti, Leggi e decreti del Regno d'Italia 1926-1929, Archivio storico del Senato, Senato del Regno, Disegni di legge, reg. 21.
} 
law of the trade unions of employers and employees. These law also be established the judiciary labor, to which had been assigned the duty to solve the conflicts at work, and which did not allow strikes and lockout. Among the implementing norms of the trade unions' law, was passed the law no. 1130 of the 1 July 1926, in which, for the first time, is named the Ministry of the corporations. This was the board decreed by the constitution of the corporation, which joined together the representatives of "the various factors of production"7 and the law of 2 July 1926, no. 1131, establishing the Ministry of corporations, which art. 1 defined: "the minister of the Corporations and under his direction the prefect of the provinces exercise all the functions of organization, coordination and control entrusted to the Government by the law 3 April 1926, no. 563 and the relative norms of actualization". ${ }^{8}$ In the beginning the Ministry did not have, therefore, administrative tasks but those of study, general coordination and control of policy and administration of trade unions. As Mussolini himself had the occasion of affirming, in his inaugural speech on taking over as minister of the Corporations on the 31 July 1926, the new Ministry was "the organ trough which at the center and on the sides take place the balances between the interests and the forces of the economic and social actualization that is possible on the ground of the state since it is only the state that transcends the contrasting interest of individuals and of groups in order to coordinate them into superior end". 9 In a speech pronounced in the House of Representatives in 1927 Bottai describes in this way, the structure, prerogatives and activities of Ministry:

The Ministry of the corporations does not yet have its definite characteristic and autonomous asset in the balance of the State; on which, usually, and for the trimming down of its organism and for the availability of its own fund, which will be formed with the quota of ten percent, to be taken from the contributions which normally go to the trade union associations, and on which it will weigh, in a rather modest way, and after taking into consideration its particular physiognomy. However, while waiting for its balance, the Ministry of corporations, has acquired, for the value of the idea that takes shape in it, his own typical position, which joins itself indissolubly to the characters which are more appropriate to the Fascist Regime. In the Ministry of the corporations, in fact, a system forms and perfects itself, as is logical and necessary; a system which the trade unions, an instrument of social and political revolution, sets up into a public board, an indirect organ of the action of the State [...] Now, the Ministry of the corporations is, exactly, a delicate and complicated "organ of connection" a center which receives, coordinates and disciplines and radiates the social energies, which converge in it and line up from all sides, in order to be immersed into the State, from where it obtains a directive of action and prestige of authority [...] It is a complex of collegial and representative organs, of technical and scientific commissions and special services. ${ }^{10}$

\footnotetext{
${ }^{7}$ Ibidem Regio Decreto $1^{\circ}$ luglio 1926, n. 1130, art. 42.

${ }^{8}$ Ibidem Regio Decreto 2 luglio 1926, n. 1131, art. 1.

${ }^{9}$ ACS , Archivi fascisti, Carte della cassetta di zinco, Autografi del duce, sc. 3, cart. 4.1.6 .

${ }^{10}$ Archivio Storico Fondazione Mondadori , Fondo Giuseppe Bottai , Carriera politico - militare, letteraria, b. 4, fasc. 16; Fondazione Ugo Spirito e Renzo De Felice, Giuseppe Bottai, b. 1, fasc. 4.
} 
The birth of the Ministry did not bring about, as envisaged in the laws of 1926, the creation of the corporations. The delay in the birth of the corporations is mainly due to two orders of reasons: in the first place, because between the theoretical persons of the corporate State and in the same government teams, it was not yet clear what type of role and structure should belong to the corporations, and in second place because the fascist trade union associations and "[the] national confederation of industry which now tended to assume an antagonistic position against the corporation, but which is of a fundamental importance in the fascist way of thinking" "11 they feared that when these corporations would start functioning they would be overwhelmed on an operative plain and in their relations with the State.

Before we pass to the analysis of activities of the Ministry, it is useful to analyze which were the theories and the interpretations of the corporatism, which had already spread even before the birth of the corporative organs. In fact, there were some who interpreted it according to a statist way, others in a liberal way, and others still who considered corporatism in terms that were strictly trade unionistic and directed towards the limitation of the economic power of the great private industry.

One of the earliest and most important theories, even for the practical applications which it had in the drawing up of the trade union law which had, among its applicative norms, the norm that instituted the corporations and the Ministry of the corporations, is the one supplied by Alfredo Rocco who intended to the social conflict through the corporations. This process had to take place through the constitutions of mixed trade unions, where should have been represented the industrials and the working force belonging to a determined productive sector, that is, the corporations. In fact, these corporations, so that they could function as social pacificators and driving forces of economic development, would have had to be driven by the State. In turn, the latter, through the regulation of the trade union activities, would have exercised a total control on the discipline of relationships at the place of work. According to Rocco the corporatism, which was distinguished by strong authoritative accents, therefore had to be that judicial system - institutional system which would have realized the submission of the social and economic forces to the superior interest of the State, and thanks to the corporations it would have been possible, by overcoming the social conflicts, to render

${ }^{11}$ ACS , SPD, CR, fasc. 242/R; Archivio Storico Fondazione Mondadori, Giuseppe Bottai, Carriera politico militare, letteraria, b. 3, fasc. 15, Fondazione Ugo Spirito e Renzo De Felice, Giuseppe Bottai, b. 1, fasc. 1 . 
efficient and efficacious the productive system, while it avoided the useless internal competition, and concentrating all forces in order to best face the international competition.

Another idea of corporatism was that of Giuseppe Bottai, the originator of the Ministry and of the first corporative structure of the State. For Bottai corporatism would have had a role in the government and regulation of the normal internal dialectic of the various social classes and so be the confrontation ground of the social petitions and the State. The corporations, were, therefore, a means for the assembly and the politicization of the various economic categories; in other words, they were a means to concede the juridical and political recognition of the social and economic forces, in such a way that these forces, once recognized, could in turn be recognized in the political field, thus making coincide State and society. In Bottai, corporatism distinguished itself, above all, as an instrument for the economic programming and the various corporative boards served to render the State free of all the conditioning imposed by the representatives of the economy. Besides, these boards, were supposed to be able to dictate the rules and addresses of the economic policy even to the government itself. ${ }^{12}$ Another interpretation which, in some way, found a practical application in the trade union legislation, was the one proposed by the fascist trade unions which, in due time, expressed, even in their plurality, some common points on how the corporative state should have been. Two of the main exponents of the fascist trade unionism Del Giudice ${ }^{13}$ and Rossoni, on various occasions and in open controversy with other theorists of corporatism, reaffirmed that the representation of the economic classes was due to the trade unions and not to the organs of the State; this controversy continued beyond the middle of the 30s when trade unionism abandoned the diatribe with the corporative boards, and the first one before all others, the Ministry of the corporations, and started to outline its own idea of corporative state. This idea consisted in entrusting to the corporations the intermediary role, through which one could obtain reforms from the State, in the sphere of assistance and social security for the workers. At the same time one was demanding that the corporations would function as instruments of control and of economic programming, so that one could regulate the initiative of private industry and free market. Various interpretation of corporatism was expressed along the years by Ugo Spirito. The Spirito's first theory was based on the idea that reconciliation should not happen between the social classes and the State but rather between the latter and the individual: the solution to this conflict was in the corporative state which

\footnotetext{
${ }^{12}$ Fondazione Mondadori, Giuseppe Bottai, Carriera politica-militare e letteraria, bb. 3, 4 e 5; Fondazione Ugo Spirito e Renzo De Felice, Giuseppe Bottai, bb. 1-10.

${ }^{13}$ Fondazione Ugo Spirito e Renzo De Felice, Riccardo Del Giudice, bb. 1-10.
} 
considered the initiative of private industry as the most useful element for national interest and in therefore rendered entrepreneurs responsible for production before the State. ${ }^{14}$ In this way one eliminated every difference between the public and the private, the corporation assigned public fines to private property, thus transforming the company into a corporation ${ }^{15}$ and assigning to it the control both to the entrepreneurs and to the workers, in this way one would have obtained "the property corporation". This thesis, presented by Spirito at the Conference of trade union and corporative studies, held in Ferrara in $1932^{16}$, aroused quite a few controversies and the resentful reply of the minister of Corporations, Bottai, who held that the theory of Spirito was an exaggerated thrust towards socialism; nevertheless Spirito had discussed this thesis with Mussolini in a meeting held in March 1932 and from whom he obtained the approval ${ }^{17}$ and recognition of the validity of his theory. After the controversies aroused by his thesis, Spirito directed his theorization towards a vision of corporatism as a means to realize a planned and programmed economy seeing in it practical carrying out of his theory in the legislation on the authorization for the creation of news industrial companies and in the birth of the IRI. ${ }^{18}$ According to Camillo Pellizzi the corporations were created, in the first place, because the class struggle and the struggle between the entrepreneurs themselves instead of taking place in a deregulated way and for individual ends, it was decided under the control of the State in an ordered way and collective finality; secondly the corporation had to function as well as a center of projection of economic plans and future products; in this sense, according Pellizzi, the corporation had one "negative function [...] as the composer of quarrels, but also a positive function, as an coordinating organ of future economic activities". ${ }^{19}$ The last interpretation that is offered to us here, is that Mussolini which was given when most of the corporative organs were formed, on the 14 November 1933 at the closure of the works of the National council of corporation. Mussolini held that "corporatism is disciplined economy and therefore also controlled [...] Corporatism surpasses socialism and liberalism, creates a new synthesis". ${ }^{20}$ Mussolini attributed to corporatism a finality of economic policy, holding that without a politicization of the economic choices and a real

\footnotetext{
${ }^{14}$ Colloquio tra Spirito e Mussolini del 17 maggio 1933, Fondazione Ugo Spirito e Renzo De Felice , Ugo Spirito, Manoscritti (MUS), b. 23

${ }^{15}$ Ibidem, b. 3

${ }^{16}$ Ibidem, MUS 52 e 27.

${ }^{17}$ Ibidem, b. 23

${ }^{18}$ Ibidem, MUS 18 a.

${ }^{19}$ Fondazione Ugo Spirito e Renzo De Felice, Camillo Pellizzi, Attività scientifica, b. 15, ms. 33, Oltre la Corporazione.

${ }^{20}$ Benito Mussolini, Discorso pronunciato al Consiglio Nazionale delle Corporazioni 14 novembre 1933 - XII, Asti, Cassa di Risparmio di Asti, 1933.
} 
political address of the address of the economy could not certainly solve the problems of social conflict and of the economic development of the Country. Nevertheless, the head of fascism, as well as the prime minister of the Corporations, never spoke of the concrete modalities through which one could reach these goals. As a conclusion of this overview one can affirm that the two theories which largely influenced the construction of the corporative state were those of Rocco and Bottai, both of which, in fact, offered a practical actualization to their theories, the first one through the drawing up of the law of trade unions of 1926, and the second through the ideas, the construction and the guide of the Ministry of corporations.

Both Rocco and Bottai collaborated actively in the drawing up of the Carta del lavoro, the only really activity carried out by the Ministry of corporations between 1926 and 1929 . The Carta fixed the main points of the new trade union law and of the structure that should have assumed the labor relationships. ${ }^{21}$ A commission for the study of the formalities for the realization of the Carta was set up in January 1927 by the Great council of fascism. In the preliminary relation on the draft of the Carta, addressed to Mussolini on 19 April 1927, Bottai wrote:

The first fruit of the initiative for the Carta del lavoro was that of giving a contribution to the will and capacity of collaboration of the various professional organizations. Besides the Trade union confederations, there were called to express their opinion, the Association of public employment, the Opera nazionale dopolavoro, of maternity and childhood, of the Balilla and of the employers, and various experts in various matters of questions [...]; if some of them kept themselves on general ones, thus shoving to want to restrict the field of the Carta del lavoro to the problem of the collective agreement, at most extending it to that of the assurance and social security, almost all the big confederations had studied very deeply the complex questionnaire, trying to understand fully, even if in a different way, the real meaning of the much awaited document, which was an expression not so much of class claims but a complete synthesis of the moral problem and the economic problem, of the interests of work and of those of production. ${ }^{22}$

The Carta del lavoro was divided under various titles concerning: the corporative state, the work contract, the offices of employment, social security and instruction. In spite of the propaganda of the regime, which had made of it the stronghold of social peace the Carta del lavoro was nothing else than the certification of the enunciations which were previously expressed in the trade union law and in its implementing norms.

\footnotetext{
${ }^{21}$ ACS , Segreteria Particolare del Duce, Carteggio Riservato, b., 4 fasc. 64/f; Archivio Storico Confindustria , Circolari, circ. n. 800 del 5 agosto 1927, Archivio Storico Fondazione Mondadori , Giuseppe Bottai, Carriera politico - militare, letteraria, b. 3, fasc. 15, Fondazione Ugo Spirito e Renzo De Felice , Giuseppe Bottai, b. 1, fasc. 1.

${ }^{22}$ Archivio Storico Fondazione Mondadori, Giuseppe Bottai, Carriera politico - militare, letteraria, b. 3, fasc. 15; Fondazione Ugo Spirito e Renzo De Felice, Giuseppe Bottai, b. 1, fasc. 1.
} 
The period between the launching of the Carta del lavoro and the abolition by the Ministry of national economy and therefore the assumption of new duties on the part of Ministry of corporations (1927-1929) served Bottai to establish firmly the ministerial structure and to favor the widening of the area of interest of the Ministry. This widening would have brought contrasts with the rest of government team, which through the will of the same Mussolini were always resolved in favor of the Ministry of corporations, since he considered the latter Ministry as being the better instrument for the needs of the economy and of the fascist state. All these facts put together brought about in 1929 the abolition of the Ministry of national economy and the division of the its duties between the Ministry of corporations, to which befell those related to industry, commerce and credit, and the Ministry of agriculture. On the assumption of these new duties the Ministry of corporations became the real nerve center of the fascist economy.

For a more efficacious understanding of the development of the corporative activity in the various sectors of the economy one can refer to a report of the Fiat's studies office, compiled in 1937, entitled "Towards the corporative constitution of the industry, corporations and consortiums", in which it was claimed:

\begin{abstract}
One is therefore recognizing the fact that the activity of the State in the presence of the productive energies becomes, for all, a very small discipline; then, differentiating the various energies according to the mentioned aspects, it penetrates ever more into the heart of private forces, little by little, through one verse or another, these show that they have, with the supreme interests of the Nation, a penetration which is more profound and more delicate. Thus at the base of the scale, we find, so to say, agriculture and craftsmanship, in which prevail and will prevail private initiative, especially for traditional reasons. A little above we find internal commerce, the small and medium industry, always in the area of private initiative, but with a greater bite in the corporate self-discipline. On top, then, remain the big industry, foreign trade and credit, where the national interest appears so prevalent as to justify a always stronger state interference; but, even here, this forecast according to different grades: 1) efficient control; 2) mixed management (private firms, of which the State owns part of the capital); 3) indirect management (private firms, of which the State owns all the capital); 4) direct management (state and parastatal firms; monopolies). Like all other classifications, this one as well is arbitrary. But, on the whole, it seems to us that it makes evident the basic characteristics of the new Italian order of production: and, that is, a will for state control, which covers all the economic life and makes itself more clear and detailed in the scale of productive firms. ${ }^{23}$
\end{abstract}

From this relation can be inferred a series of corollaries on the interventions put in action by the Ministry of corporations in the economic field: first of all, it worked for the stabilization of the relationship between the firms and the workers, reducing, through the

${ }^{23}$ Archivio storico Fiat, Fiat Capogruppo, Ufficio Statistiche e Studi Economici, Servizio statistica e studi economici, scat. 8, fasc. 572, pp. 14-15. 
trade union laws, the social conflict and so, contributing towards an improvement in the production of the factories and in the agricultural structures. Always on the theme of reducing the social conflict, it also tried to bring about a reconciliation of the relationship between the producers and the consumers through the control of the policy of price. Secondly, it established policies to favor the Italian industry guaranteeing it through protection's barriers in the face of foreign competition; conceding fiscal favors, and other favors in term of financing for the realization and the development of plants; besides, it also contributed, through its directed intervention, to the production of exports and the control of market quotas of Italian firms abroad. Thirdly, it acted, through the public economy boards, as an active subject and not only as an arbiter of economic events; in fact, although it seems that these boards were acting in a totally autonomous way in respect to the directive of the Ministry, in reality it was not so, as is shown by the presence of a representative of the Ministry inside the boards of administration of all firms in which the State has some sort of participation. Then very meaningful is the role exercised by the Ministry in the management and control of credit and in the credit firms. From the first aspect of the activity, over and above what has been said as regards of the Carta del lavoro, one can point out how, through various measures and institutes, the Ministry tried to put into practice a policy to control the prices of raw material, on the prices of consumer goods, on the taxes ${ }^{24}$, and here one can speak of consumers in a side sense, that is not only the consuming of retail goods but also and especially the sale of raw materials and unfinished products to industry. Always for the protection of the consumer one can mention the interventions of the Ministry against the fraud in foodstuffs. As regards the relations between the Ministry and the big industry one can find in the archives of the firms and in the institutional archives, numerous examples of such activities. One can quote laws on the obligatory consortia of 1931-1932, which, initially, provoked a strong negative reaction of the industrialists who were afraid that in this way they were perceiving the limitation of their free initiative, as one can read in the report of the Fiat's studies office, quoted earlier:

The most tenacious opponents of the consortia model have held [...] that the consortium limits private initiative [...] In reality the consortium its itself the fruit of private initiative; which however, after taking into consideration the risks and damage, individual and collective, of economic atomism, subjects itself voluntarily

\footnotetext{
${ }^{24}$ Archivio Storico della Camera dei Deputati , Archivio della Camera Regia, Disegni e proposte di legge e incarti di segreteria, vol. 1362, fasc. 2462; ASBIT, Ispettorato per l'esercizio del credito e la tutela del risparmio, Generico, fasc. 1-30; ACS , MICA, Camere Agrumarie .
} 
to certain collective norms, which is then up to the corporation to harmonize with the national aims. ${ }^{25}$

The law, instead, favored the control of the Confindustria on the formation of consortia and made indispensable, to present the request for come together in consortium, that the firms which wanted to form part of it, had to present at least $70 \%$ of the firms employed in that productive sector. ${ }^{26}$ The law concerning the authorization for the construction of new industrial plants, aimed, like the preceding law, to protect the interests of the big industries, more than rendering available to the whole productive system the possibility of enlarging or constructing new industrial factories. Always according to the report of the Fiat's studies office the law had respect various criteria: the control of the war constructions and those of the economic dimensions of production. ${ }^{27}$ The interventions were made with the governments of foreign countries to protect the market quotas reached by the principal Italian industries. ${ }^{28}$ There were also the policies in terms of protection of Italian products against foreign firms, through the increase of custom duty. There were evident also all the instruments of control of the production and of the plants, put in action by the Ministry, both through the corporative inspectorates and through the Industrial Observer. ${ }^{29}$ Concerning business with foreign countries one can notice the financings conceded to the IMI, with the subsidiary guarantee of the State, through policies issued by the INA, to the firms exporting to countries in eastern Europe, especially the URSS. The mechanism used was that of the discount of the bills of exchange issued by the Representative in Italy for foreign commerce of the URSS, the supplies were insured with policies issued by the INA which guaranteed their payment, in order to benefit from this facilitated financial system were principally the mechanic industries. ${ }^{30}$ Always in this field one can consider the financial investments conceded by the

\footnotetext{
${ }^{25}$ Archivio Storico Fiat, Fiat Capogruppo, Ufficio statistiche e studi economici, Servizio statistica e studi economici, scat. 8, fasc. 572.

${ }^{26}$ Ibidem; ACS , PCM, Gabinetto, Atti, 1937-1939, fasc. 3.1.2/3510, ACS, MICA, Consorzio trebbiatori, ACS, MICA, Consorzio Bergamotto.

${ }^{27}$ Legge 12 gennaio 1933, n. 141. Archivio Storico Fiat, Fiat Capogruppo, Ufficio statistiche e studi economici, Servizio statistica e studi economici, scat. 8, fasc. 572; ACS , ASIRI, Pratiche societarie, Documentazione senza titolario; ASBIT, Ispettorato per l'esercizio del credito e la difesa del risparmio , Generica; Archivio Storico Confindustria , Giovanni Balella, Problemi economico - industriali; Fondazione Dalmine, Dalmine, Direzione affari generali; Fondazione Ugo Spirito e Renzo De Felice, Ugo Spirito, Manoscritti Ugo Spirito, MUS 18/a.

28 Archivio Storico Fiat, Fiat Capogruppo, Ufficio statistiche e studi economici, Servizio statistica e studi economici, scat. 6, fascc. 417, 446, 458; ACS , PCM, Gabinetto, Atti 1931-1933, fasc. 1.1.30/9801; Archivio Storico Confindustria , Giovanni Balella , Problemi economico industriali.

${ }^{29}$ ACS , MICA, Osservatori Industriali ; ACS, Ministero del Lavoro e della Previdenza Sociale , Ispettorato del lavoro .

${ }^{30}$ ASI-IMI, Serie Mutui, Serie mutui ordinaria, pratiche 85, 91, 145, 167, 206, 213, 214, 223, 237, 245, 249, $254,255,261,271,279-281,291,292,295,299-301,312,314,318,320,322,323,328,329,332-335,337-$
} 
CSVI to the industries which were exporting war material to the countries of eastern Europe, URSS, Hungary and Romania following agreements between the Italian government and that of the other states. ${ }^{31}$ Even the policies established for the realization of the autarchic plans can be included among those of industrial policy. In the definition of Camillo Pellizzi:

\begin{abstract}
Autarchy started to mean that, not only as a fact or buy fortuitous coincidence of various circumstances, but as a principle and with a deliberate purpose, the fascist state made itself the initiator and organizer of what has been called "the national economic company". In this, the individual initiative, in order that it may converge to its collective purposes, is encouraged and empowered: by every selfishness private, both as regards concept and practice, is definitely destined to disappear [...] Autarchy, that is, the state empowerment which is not only any longer conditioned by foreign commerce, but unhooked from that one; and as a consequence, a financial investment of the economic activity which is no longer based on the capital reserves, public or private, but on the effective possibilities of useful production latent in the country and in its people..$^{32}$
\end{abstract}

In the report of Di Nardi, a director of the Bank of Italy, on the financing of the autarchic plans we read:

\begin{abstract}
Our structure of crediting is prepared to face these new duties. The reform of the banking system has created the necessary organs for long term financing, offering appropriate guarantees of tranquility to the savers. The praxis of these last few years, in which very important financial transactions have taken place, has strengthened the structure of the IMI ant that of the IRI, which can acquit the autarchic plans through an ulterior empowerment of their activity. ${ }^{33}$
\end{abstract}

It was very peculiar when, the manner in which was structured the Comitato tecnico consultivo IMI - Autarchia economica nazionale ${ }^{34}$, which was in fact formed in two distinct committees, one dependent on the CNR and it had the task of valuing the merits of a project and the other internal to the IMI, in which participated also a representative of the Ministry of corporations, and it had the task valuing whether a project was feasible, economically (NEMORE, 2015). And likewise surprising were the modalities for the concession of financing, to most of the companies that had made the request, as a dispensation to the normal praxis followed by the IMI, in the minutes of Executive committee of the Institute one can in fact read:

340, 352, 360, 366, 377, 385, 389, 390, 398, 402-404, 406, 409, 410, 414, 419-421, 428, 431, 434-436, 454, 463, 465, 499, 500, 514, 529, 533, 557.

${ }^{31}$ ASBI, Archivi Aggregati, Consorzio per Sovvenzioni su Valori Industriali , Operazioni speciali.

${ }^{32}$ Fondazione Ugo Spirito e Renzo De Felice, Camillo Pellizzi, Attività scientifica, b. 15, ms. 33.

${ }^{33}$ Archivio Storico della Banca d'Italia (ASBIT), Direttorio Azzolini , b. 90, fasc. 1, sfasc. 5.

${ }^{34}$ ASI - IMI, Serie mutui, Serie mutui gestione speciale autarchia; Serie mutui ordinaria; Verbali del Comitato Tecnico Consultivo IMI - Autarchia Economica Nazionale. NEMORE, Francesca. La documentazione del fondo "Gestione Speciale IMI Autarchia Economica Nazionale. Archivi, IX/2 (luglio-dicembre 2014). 
The IMI has up to now refused, in conformity with the usual decisions taken by the Council of administration, the requested operations for the development of new industrial initiatives which would not have adequate subsidiary guarantees [...] When considering the directives which help to reach the economic autarchy, the IMI was asked to intervene for the financing of new industrial initiatives of private industries which would have solely in part [...] the necessary means for a new industrial initiative or for the exploitation of new procedures or patents, always when there exist exceptional circumstances of an economic or political order, and which are of particular interest to the economic autarchy of the Nation [...] The Committee of ministers for the protection of savings and the exercise of credit in the meeting of 4 of current month, has approved that one accords [...] the guarantee of the State to a special series of obligations 5\% [...] The operations with the availability of placing obligations helped with the guarantee of the State will be administrated separately and would constitute a special management on behalf of the State. ${ }^{35}$

Of particular interest for the continuation of the discourse and the story that the two had during the republican period were the conditions which led to the birth of IMI and IRI, respectively in 1931 and in 1933, and in this case one may speak of an intervention in industrial policy and intervention in the field of the crediting. The two boards had in fact created in order to bring an end to the crisis of the fixed assets in which were found to be involved two of the major Italian banks, the Banca Commerciale Italiana and the Credito Italiano. Till the banking reform of 1936 the institutes of credit worked as mixed banks, that is both as the normal deposits of current accounts and the long and medium term credit to industries, and precisely through this system, the two banks became the owners of the packets of shares of a number of major Italian industries, Terni, Ansaldo, SIP, Edison and many others, which were operating in strategic sectors of the economy. Nevertheless, since the industries were not succeeding in covering their debts, the banks found themselves in the situation in which the amount of the fixed assets surpassed by far both the deposits as well as their social capital and therefore were no longer in a position to effect the normal bank operations, thus risking to go bankrupt, as happened in 1921 to the Banca Italiana di Sconto. In 1931 the Comit and the Credit found themselves obliged to ask once again for the help of the Government in order to overcome the period of crisis: the Credit requested a loan from the Bank of Italy, the Comit asked, instead, a real rescue operation from part of the State. At first the government tried to find a solution through the creation of the IMI, a company of public right having the aim of conceding medium and long term investments to the Italian Companies. In the inaugural addresses of Mussolini and Mayer, president of IMI, the Institute was fitted into the corporative development of the State. Mussolini, in fact, said "Considering

${ }^{35}$ ASI-IMI, Verbali del Comitato Esecutivo, Reg. 5, pp. 186-188. 
the IMI as a means to direct energetically the Italian economy towards the corporative phase in exact, that is to a system which basically respects private property, but which wants itself as well inside the State which alone can protect, control and given life to one and the other". ${ }^{36}$ And Mayer in reply to those who feared that the birth of the IMI would have led to the nationalization of many enterprises, said that:

Many misunderstandings, even of a doctrinaire nature had been faced on the horizon of previsions. They had even talked of a process of a nationalization of the industries, without taking into account that the only enunciation of a similar principle contains the most serious contradictions with the spirit and letter of the corporative economy [...] One should not confound the principle of nationalization with the corporative principle, since this, which is at the basis of the renewed and renewing Italian life, aims mainly to the conciliation of the interests of individuals with the general interests of the Country, to the free exercise of the private activities in this field and for the purposes of the national economy, to the general interest of the State dominating the particular interests, to the harmony of single forces with the collective ones. ${ }^{37}$

The IMI, according to Toeplitz, the president of the Comit, had to serve to lighten the financial situation of the bank, conceding loans to the companies in difficulty and which, through these investments, could have been able to plan again, at least in part, the exposure they had towards in Comit. The expectations of Toeplitz, however, were to be disappointed from the speeches which Mussolini and Mayer pronounced at the inauguration of Institute. Mussolini affirmed that the IMI "should not be there to try to save failing organisms or those on their way to failure: but they should help the healthy financial economic forces, to which the world economic crisis was making their way forward particularly difficult" ${ }^{\prime 38}$ and Mayer said "it is not one of the functions of the Institute to correct the mistakes or to heal the mistakes of others, not that of replacing, through complicated and dangerous financial operations, the foundations of those enterprises, of which, for various reasons, the calculations of construction had been mistaken". ${ }^{39}$ As is evident these statements the IMI did not lend itself to the task of rescuing requested by the Comit and to no avail were the insistences of Toeplitz with Mussolini. ${ }^{40}$ The main point of contrast between the two Institutes was reached when the Sofindit, on behalf of the Comit, presented to the IMI three clear requests of loans, respectively for the SIP, for Italgas and for Terni, the highest of which amounted to the figure

\footnotetext{
${ }^{36}$ ASI-IMI , Servizio Studi, b. 1, fasc. 2.

${ }^{37}$ Ibidem.

${ }^{38}$ Ibidem.

${ }^{39}$ Ibidem.

${ }^{40}$ ASI - Comit , Amministratori Delegati della BCI, Carte di Raffaele Mattioli (1925-1972), Carte miscellanee di Raffaele Mattioli (1925-1972), b. 1; Carte degli amministratori delegati Facconi e Mattioli (1926-1949), 1-9 Pratiche speciali e per materia, b. 2.
} 
of three hundred and fifty million lire and was presented in the name of SIP, but was rejected by the IMI after a brief investigation; the other two, instead, were accepted, but for more inferior figures than those requested. ${ }^{41}$ Once this first rescue attempt failed, they study a new mechanism which foresaw first the passage of various packets of shares to two financial groups, the Sofindit for the Comit and the SFI for the Credit, and from these to a new State board of asset's disposals, the IRI which had the task of acquiring the various share participations, thus freeing the banks from the fixed assets, and therefore to sell them back to the private entrepreneurs. The ways of arrangement of the Comit were sanctioned with the so called Convenzione di Roma agreed on 31 October 1931 between Comit, the Bank of Italy and the Ministry of the treasury, the various passages of the salvation plan were finalized by Alberto Beneduce. For the arrangement of the financial situation of Credit, the activity started in 1930 on the instance of Alberto Pirelli. Founded in 1933, the IRI was structured in two sections: one section asset's disposals which had the task of taking on the activity and passivity of the companies in crisis and which had to be liquidated, and the other section of investment which had the task of distributing loans for a maximum period of twenty years. In an article that appeared in Critica fascista (1 February 1933) carrying the title "Statalismo corporativo", Ugo Spirito argued:

With the law for the authorization of industrial enterprises and with the institution of the Institute for Industrial Reconstruction, the fascist government has definitely place himself on the street of planned economy. No longer a casual and occasional intervention on the part of the State in the field of competence of private initiative, but an organic and continuous action carried out with the appropriate means and institutes. $^{42}$

The IRI which was supposed to be a transitory board but was transformed in 1937 into a permanent management board and it became an owner, and as a direct consequence, the State became a majority shareholder, both of the packets of shares of the various companies controlling by the banks and of the banks themselves; a very clear analysis of this state of things was given in a paper of Camillo Pellizzi, entitled "Oltre la corporazione" in which he said that

The private wealth of the nation seemed to be unsuited, on its own, to overcome the unfavorable contingency and to save those industries and there seemed necessary a global effort of the nation, in other words, a direct state intervention in the field of the so called "private economy". The State acquired, entirely or in part, a great

\footnotetext{
${ }^{41}$ ASI-IMI, Serie Mutui, Serie Mutui Ordinaria, pratiche 27 e 28 .

${ }^{42}$ Fondazione Ugo Spirito e Renzo De Felice , Ugo Spirito, Manoscritti, MUS 18/a.
}

Oficina do Historiador, Porto Alegre, EDIPUCRS, v. 9, n. 2, jul./dez. 2016 
number on industries and, in a parallel way, the principal banks became entities of public ownership, with a direct interest of the State. ${ }^{43}$

Mussolini stressed the importance of the provisions taken of the credit, affirming in front of meeting of corporations of 23 March 1936: "the recent provisions have logically brought it under the control of the State. This section is, for a thousand reasons, the absolute interest of the State". ${ }^{44}$ The IMI and the IRI, besides being placed under the control of the Ministry of treasury, also had representative on the board of administration of the Ministry of corporations and, something little know, the minister of Corporations tried, in the years $40 \mathrm{~s}$ to take control of the economic management of IRI. ${ }^{45}$

Concerning the control of the credit sector, besides the creation of the two entities just mentioned above, one should note also the participation of the Ministry in the drawing up of the "banking law" of 1936 (RDL 12 March 1936 no. 375 "Measures for the defense of the savings and the discipline of the credit functions"), which, written, as it were, in the sphere of the IRI $^{46}$, also had the participation of the corporation of credit, especially in the creation of the Ispettorato per la difesa del risparmio e l'esercizio del credito ${ }^{47}$ and a direct ministerial intervention in the Comitato interministeriale per il credito. Besides, the Ministry had to approve the statutes of the Monti di pawnshop and those of the savings bank, besides approving the budgets of various ordinary banks.

From most of the intervention acts and state control of the economy, put in place by the fascism, it is possible to compare a certain form of continuity with those practiced at the beginning of ' 900 by the liberal governments; but especially with the policies put in place and practiced during the first fifty years of life of the Republic; and particularly we meet with signs of obvious continuity especially in the perpetuating of a mixed industrial and economic system, in which the State intervenes in the market both through the regulation of the same, as well as an actor in its very sense in as much as the State is the owner of the big industries. The maintenance of the economic system put in place by fascism was, in a certain way, encouraged by the Allies at the end of the Second World War when they agreed to the

\footnotetext{
${ }^{43}$ Fondazione Ugo Spirito e Renzo De Felice, Camillo Pellizzi, Attività scientifica, b. 15, ms. 33.

${ }^{44}$ Archivio Storico Fiat, Fiat Capogruppo, Ufficio statistiche e studi economici, Servizio statistica e studi economici, scat. 8, fasc. 572, relazione Verso la costituzione corporativa dell'Industria corporazioni e consorzi, p. 15.

45 ACS , ASIRI, Pratiche degli uffici, ex Archivio storico, Studi e memorie sull'IRI dal 1933 al 1954,1933 1943, b. STO/521.

${ }^{46}$ ACS , ASIRI, Pratiche degli uffici, ex Archivio storico, Risanamento delle banche di interesse nazionale finanza IRI , Banche di interesse nazionale, Comit, Credit, Banco Roma (1933-1939), b. STO/480.

${ }^{47}$ ASBIT, Ispettorato per l'esercizio del credito e la difesa del risparmio e Direttorio Azzolini.
} 
resumption by the IRI of its activities. In the process they kept unaltered the structure of state holdings, and entrusted to the IMI the management of the investments of the industrial reconstruction erected by the European Recovery Program (ERP).

The State intervention in the economy had its own continuity and ulterior developments and unfailing distortions almost till the end of the years 90s when the State entrepreneur decided to privatize almost all the industries with state participation, maintaining in some of theme a small participation, or else the so called "golden share", that is, the possibility given to the Ministry of the treasury of retaining the power of decision and of control concerning the eventual selling of shares of various societies.

\section{BIBLIOGRAFY}

BATTELLI, Giulio Archivi, biblioteche ed opere d'arte: ricordi del tempo di guerra 1943 1946. Miscellanea Bibliotecae apostolicae vaticanae, 7, Città del Vaticano, Biblioteca Apostolica Vaticana, 2000.

BIDOLLI, Anna Pia. Fonti per la storia delle imprese nei Ministeri economici. Rassegna degli Archivi di Stato, XLIX/1 (1989), pp. 98-100.

BORSI, Franco; MOROLLI, Gabriele; FONTI, Daniela; BATTAGLIA, Adolfo, Il palazzo dell'Industria. Roma: Editalia, 1986.

CAPACCIONI, Andrea; PAOLI, Andrea; RANIERI, Ruggero Le biblioteche e gli archivi durante la seconda guerra mondiale. Il caso italiano. Bologna: Pendragon, 2007.

GENCARELLI, Elvira, Gli archivi italiani durante la Seconda Guerra Mondiale. Roma: Ministero per i Beni Culturali e Ambientali, 1979.

GIUVA, Linda; GUERCIO, Maria. III. I Ministeri economici. In: MELIS, Guido (Ed.). L'amministrazione Centrale dall'Unità alla Repubblica. Le strutture e i dirigenti. Bologna: Il Mulino, 1992.

Ministero dell'Interno, Direzione generale dell'amministrazione civile, Ufficio centrale Archivi di Stato. Gli archivi di Stato al 1952. Roma: Istituto Poligrafico dello Stato, 1954.

NEMORE, Francesca. Guida alle fonti sussidiarie per la storia del Ministero delle Corporazioni. Tesi di Dottorato di ricerca in scienze librarie e documentarie, XXV ciclo. Dipartimento di Scienze documentarie, linguistico-filologiche e geografiche. Università degli Studi di Roma La Sapienza. 2013.

- La documentazione del fondo "Gestione Speciale IMI Autarchia Economica Nazionale. Archivi, IX/2 (luglio-dicembre 2014). 
La politica autarchica del fascismo: tra industria e ricerca scientifica. Il Mondo degli
Archivi,
A.
III
(novembre
2015)

http://www.ilmondodegliarchivi.org/index.php/studi/item/646-la-politica-autarchica-del-

fascismo-tra-industria-e-ricerca-scientifica.

PAOLI, Andrea, "Salviamo la creatura": protezione e difesa delle biblioteche italiane nella seconda guerra mondiale. Roma: AIB, 2003.

RE, Emilio. Gli archivi italiani durante la guerra. Archivio della Deputazione romana di Storia patria, vol. LXIX (XII n. s.), fascc. I-VI, Roma 1946.

I danni di guerra subiti dagli archivi italiani. Notizie Degli Archivi di Stato, aa. IVVII, n.u., Istituto Poligrafico dello Stato, Roma 1950.

TOSCANO, Mario, Gli archivi segreti d palazzo Chigi catturati dai nazisti nel 1945. Nuova antologia, XCVI (1961).

ARTIGO ENVIADO EM: 12.07 .2016

ACEITO PARA PUBLICAÇÃO EM: 07.09.2016 